\title{
Detection and Sequence Diversity of Begomovirus Associated with Yellow Leaf Curl Disease of Pepper (Capsicum annuum) in West Sumatra, Indonesia
}

\author{
JUMSU TRISNO $^{1,2^{*}}$, SRI HENDRASTUTI HIDAYAT ${ }^{1}$, TRIMURTI HABAZAR $^{2}$, \\ ISHAK MANTI ${ }^{4}$, AND JAMSARI ${ }^{3}$,
}

\author{
${ }^{I}$ Department of Plant Protection, Faculty of Agriculture, Institut Pertanian Bogor, \\ Darmaga Campus, Bogor 16680, Indonesia, ${ }^{2}$ Department of Plant Pests and Diseases, ${ }^{3}$ Department of Agronomy, \\ Faculty of Agriculture, Universitas Andalas, Limau Manis Campus, Padang 25162, Indonesia \\ ${ }^{4}$ Balai Pengkajian Teknologi Pertanian Sumatera Barat, Sukarami, Solok, PO. Box 34, Padang 25001, Indonesia
}

\begin{abstract}
Yellow leaf curl disease of pepper has become an emerging important disease in West Sumatra since early 2000. Several attempts have been made, including disease survey and detection, in order to identify the causal agent of the disease. Pepper (Capsicum аппиит) plants showing yellow leaf curl from West Sumatra were analyzed for presence of Begomovirus employing Polymerase Chain Reaction (PCR) with degenerate primers pAL1v 1978 and pARc 715. A DNA fragment of $1.6 \mathrm{~kb}$ was successfully amplified and subjected to direct sequencing. A stem loop region was found in the nucleotide sequence obtained, which contains the conserved nucleotide signature sequence TAATATTAC present in begomoviruses. Based on the stem loop region comparisons and phylogenetic analysis, the virus isolates from West Sumatra showed the closest relationship to Pepper yellow leaf curl Indonesia virus (PYLVIV) and Tomato yellow leaf curl Indonesia virus (TYLCIV). The sequence was different from other Asia Begomoviruses reported earlier. These isolates were divided into three groups which were tentatively called Pepper yellow leaf curl Indonesia virus-West Sumatra-[group 1], -[group 2] and -[group 3] \{PYLCIV-WS-[group1], -[group2], and [group3]\}.
\end{abstract}

Key words: begomovirus, pepper yellow leaf curl virus, sequence analysis

Begomovirus is a member of family Geminiviridae, which is largest group of plant viruses. The geminivirus is a group of plant viruses with distinct morphological characteristies. It's twinned isometric particles consist of circular singlestranded (ss) DNA genomes (Gutierrez 2000). Geminiviruses are subdivided into four genera on the basis of host range, insect vector and genome organization. The genus Begomovirus (sub group III) consists of viruses that are transmitted by whiteflies to infect dicotyledonous plants with a monopartite or bipartite arrangement (Fauquet and Stanley 2003). Begomovirus assosiated with pepper yellow leaf curl disease has become a major problem chillie pepper growing and causes crop damage in many tropical and subtropical regions wordwide (Varma and Malathi 2003). In Indonesia, a virus infection causing yellow mosaic, upward leaf curling and stunting was observed infecting pepper throughout production area in West Java, Central Java and Jogyakarta. Begomovirus-association with this disease was confirmed using polymerase chain reaction (PCR) method, and the virus was tentatively named pepper yellow leaf curl virus (PYLCV) (Sulandari 2004). Early studies conducted by Rusli et al. (1999) and Sulandari (2004) showed that PYLCV was not either seed or mechanically-transmitted, although the virus was easily transmitted through grafting and whitefly, Bemisia tabaci Genn. (Hemiptera: Aleyrodidae).

Characterization of a partial genomic sequence of the PYLCV was reported later (Sukamto et al. 2005; Hidayat et al. 2006). The begomovirus associated with yellow leaf curl disease in pepper in West Java (accession number AB246170) showed the highest sequence identity of 93 and $98 \%$ with

"Corresponding author:, Phone: +62-751-72701,

Fax:+62-751-72702, E-mail: ano_trisno@yahoo.co.id pepper yellow leaf curl Indonesia virus (PYLCIV) from Capsicum annuum (AB189845) and PYLCIV from Lycopersicon esculentum (AB189850), respectively.

Occurrence of pepper yellow leaf curl disease was reported from almost all pepper growing areas in Indonesia (Directorate of Plant Protection, personal communication), including West Sumatra. A preliminary survey in several regions in West Sumatra showed that disease incidence could reach $100 \%$ (Syaiful 2005). In this paper, we reported sequence analysis of the intergenic region isolated from eleven begomovirus isolates infecting pepper plants collected from different location in West Sumatra.

\section{MATERIALS AND METHODS}

Sample Collection. Pepper plants showing typical symptoms of begomovirus infection (yellow mosaic, leaf curling, smaller leaflet, cupping and stunting) were collected from several pepper producing areas (18 areas, 6 district) in West Sumatra (Fig 1). Observation was conducted directly when the plants were at the flowering stage in the field with $300-500 \mathrm{~m}^{2}$ area. Samples were taken with purposive-randomsampling according to the typical begomovirus symptom. Five samples were taken for each location that represent each typical symptom, thus the number of samples was 90 . Samples were placed in plastic bags and carried to the laboratory for DNA extraction and to a screenhouse for virus isolation and propagation in the host plant. At the same time, disease incidence $(\%)$ was determined by counting the number of plants that showed the symptom from $10 \%$ of the plant population. The sample plants were determined according to systematic random sampling. However, desease severity was determined by using formula 1 , with a modified scale of category according to Lapidot et al. (2001). Symptom 


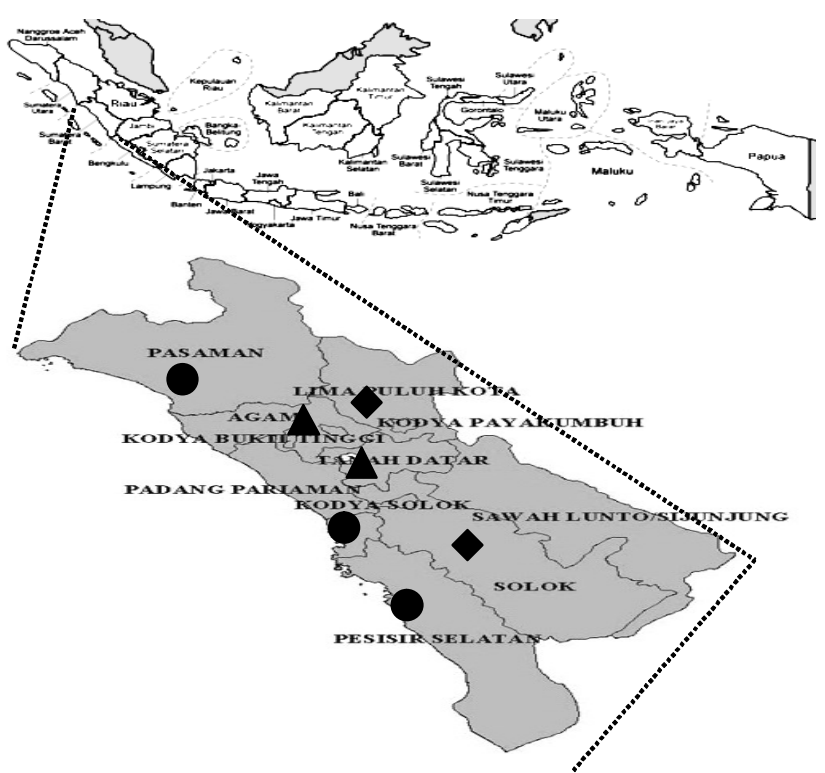

Fig 1 Sampling location in West Sumatra to collect pepperinfected begomovirus. •, low altitude $(<400$ m: Pasaman, Padang, Pesisir Selatan); , medium altitude (400-700 m: Solok, Limapuluh Kota); $\boldsymbol{\Delta}$, high altitude (>700 m: Tanah Datar, Agam).

development was evaluated according to the following scale: 0 , no visible symptoms; 1 , very slight yellowing of leaflet margin on apical leaf; 2 , some yellowing and minor curling of leafled ends; 3, a wide range of leaf yellowing, curling and cupping, with some reduction in size, yet plants continue to develop; and 4, very severe plant stunting and yellowing, pronounced leaf cupping and curling, plant growth stopped.

$$
\text { Disease severity }=\frac{\sum\left(n_{i} x V_{i}\right)}{Z x N} \times 100 \%
$$

$\mathrm{n}_{\mathrm{i}}$, sample plant in $i ; \mathrm{V}_{\mathrm{i}}$, value of symptom scale in $\mathrm{i} ; \mathrm{Z}$, value of highest symptom scale; $\mathrm{N}$, number of observed sample plants

DNA Extraction and PCR Analysis. Total DNA was extracted from pepper leaves according to the method of Doyle and Doyle (1999) with slight modification. Leaf tissue was ground in a sterile mortar in $1.0 \mathrm{~mL}$ of extraction buffer. The extraction buffer used for the initial homogenization contained $100 \mathrm{mM}$ Tris $\mathrm{pH}$ 8.0, $1.4 \mathrm{mM} \mathrm{NaCl}, 20 \mathrm{mM}$ EDTA pH 8.0 and $0.2 \%(\mathrm{v} / \mathrm{v}) \beta$-mercaptoethanol. The extraction buffer was autoclaved and $2 \%(\mathrm{v} / \mathrm{v})$ polyvinylpyrolidone (PVP) and 2\% (w/v) CTAB were added immediately before use. Immediately after grinding, $500 \mu \mathrm{L}$ aliquotes were transferred to a $1.5 \mathrm{~mL}$ microtube and incubated for $15 \mathrm{~min}$ at $65{ }^{\circ} \mathrm{C}$ with occasional mixing to avoid aggregation of the homogenate. To the extract was added $500 \mu \mathrm{L}$ of chloroform:isoamylalcohol (24:1) and the mixture was vortexed thoroughly. Each tube was then centrifuged for $15 \mathrm{~min}$ at $10000 \mathrm{x} \mathrm{g}$. The debris-free supernatant was then transfered to a new tube and proteins precipitated by adding $2.5 \mathrm{x}$ volumes of absolute ethanol and washed twice with $70 \%$ ethanol $(\mathrm{v} / \mathrm{v})$. The pellet was dried and resuspended in $100 \mu \mathrm{L}$ of sterilized water. This DNA extract was stored at $-20{ }^{\circ} \mathrm{C}$ for further use.

The begomovirus genome was amplified by the PCR technique using two oligonucleotide degenerate primers for the geminivirus, pALv1978 (5'-GCATCTGCAGGCCCACA TYGTCTTYCCNGT-3') and pARc715(5'-GATTTCTGCA GTTDATRTTYTCRTCCATCCA-3') (Rojas et al. 1993). PCR reactions were prepared in $25 \mu \mathrm{L}$ total volume, containing $10 \mathrm{x}$ buffer (100 mM Tris-HCl, $500 \mathrm{mM} \mathrm{KCl,pH} \mathrm{8.3),} \mathrm{dNTP} \mathrm{mix}$ (4 mM), $10 \mathrm{mM}$ of each primer, 1 unit of Taq DNA polymerase and $2 \mathrm{ml}$ of the DNA template. The amplification profile should be referred to Rojas et al. (1993).

Nucleotide Sequencing and Phylogenetic Analysis. The produc+t of the PCR amplification, approximately $1.6 \mathrm{~kb}$ length, was sequenced by the dideoxy-nucleotide-chain termination method with ABI-Prims 3100-Avant Genetic Analyzer (Applied Biosystem, Foster City, CA, USA) at PT. Charoen Pokphand Indonesia, Tbk, Jakarta. Sequence data obtained was compared with those of other geminiviruses - vailable in GeneBank using The National Center of Biotechnology Information basic local alignment search tool or NCBI BLAS (http://www.ncbi.nlm.nih.gov/BLAST). The sequences were aligned using Clustal $\mathrm{W}$, while phylogenetic analysis was conducted using online tool facilities available at http://www.genebee.msu.su/clustal/advaned.htm1. Results of the analysis were used to construct a phylogenetic tree and the robustness of the internal branches of the tree was tested by bootstrap analysis using 100 replicates.

\section{RESULTS}

Disease Symptoms. Our survey was conducted in 18 pepper-producing areas covering 6 districts in West Sumatra from May to October 2007 (Fig 1). It was evident that the pepper yellow leaf curl disease occurred in all the surveyed regions, with the disease incidence ranging from 37.8 to $97.0 \%$. Infection of the virus may cause various symptoms including yellowing, mosaic, curling, cupping and stunting.

Table 1 Isolate identity, observed symptoms on collected pepper samples and disease incidence of pepper yellow leaf curl disease in West Sumatra, Indonesia

\begin{tabular}{|c|c|c|c|}
\hline Location (district) & Isolate identity & Observed symptoms on collected samples & Disease incidence $(\%)$ \\
\hline \multirow[t]{2}{*}{ Pesisir Selatan } & PepPSS 1-1 & $\mathrm{y}, \mathrm{scr}, \mathrm{scp}$ & $53.0-80.0$ \\
\hline & PepPSS2-3 & $\mathrm{m}, \mathrm{scr}$ & \\
\hline Pasaman Barat & PepPBST2-3 & $\mathrm{y}, \mathrm{cr}, \mathrm{cp}, \mathrm{st}$ & $92.5-97.0$ \\
\hline \multirow[t]{2}{*}{ Solok } & PepSo2-1 & $\mathrm{y}, \mathrm{scr}, \mathrm{st}$ & $63.3-81.7$ \\
\hline & PepSo3-5 & $\mathrm{m}, \mathrm{cr}, \mathrm{cp}, \mathrm{sl}, \mathrm{st}$ & \\
\hline Limapuluh Kota & PepPYK1 & $\mathrm{y}, \mathrm{scr} . \mathrm{cp}$ & $80.0-85.0$ \\
\hline \multirow[t]{2}{*}{ Tanah Datar } & PepTD $1-3$ & $\mathrm{~m}, \mathrm{sc}$ & $37.8-71.7$ \\
\hline & PepTD2-1 & $\mathrm{y}, \mathrm{cr}, \mathrm{cp}, \mathrm{sl}, \mathrm{st}$ & \\
\hline \multirow[t]{3}{*}{ Agam } & PepAg 1-4 & $\mathrm{m}, \mathrm{scr}, \mathrm{cp}, \mathrm{sl}$ & $86.7-95.0$ \\
\hline & PepAg2-1 & $\mathrm{m}, \mathrm{cr}, \mathrm{scp}, \mathrm{st}$ & \\
\hline & PepAg2-4 & $\mathrm{m}, \mathrm{cr}, \mathrm{cp}, \mathrm{sl}, \mathrm{st}$ & \\
\hline
\end{tabular}


Symptoms variability was found for each region (Table 1). Five samples were taken from each of the 18 locations, with different and varied symptoms, so that the total samples used was. Therefore, one isolate was selected for each symptom type for further detection and identification.

Detection of Begomovirus by PCR and Sequence Characterization. Specific DNA fragments of $1600 \mathrm{bp}$ were succesfully amplified from 90 leaf samples using geminivirus degenerate primers pALv1978 and pARc715 (Fig 2). The amplified DNA fragment, denoted as "top fragment", include part of replicase gene, the full common region and part of the coat protein gene. Eleven isolates from 90 samples representing six different districts with specific symptoms were subjected to direct sequencing. These isolates consisted of two samples from Pesisir Selatan (PepPSS1-1 and PepPSS2-3), one sample from Pasaman Barat (PepPSBT-1), two samples from Solok (PepSo2-1 and PepSo3-5), one sample from Limapuluh Kota (PepPY-1), two samples from Tanah Datar (PepTD1-3 and PepTD2-1) and three samples from Agam (PepAg2-1, PepAg2-4 and PepAg1-4) (Table 1).

The sequence of the "top fragment" contains the nonanucleotide sequence 5'-TAATATTAC-3' as a part of a hairpin loop structure, and repetitive sequences known as an iteron. In his study, the hairpin loop structure was found in all sequence of begomovirus samples from West Sumatra. Variability in the structure and the length of hairpin loop region were observed among West Sumatran samples with only three samples having similar structure, i.e. PepPYK1, PepAg2-1 dan PepAg2-4 (Fig 3). The shortest hairpin loop region was 27 bases (PepSo3-5) whereas the longest was 33 bases (PepTD1-3 and PepAg1-4). The isolates with similar

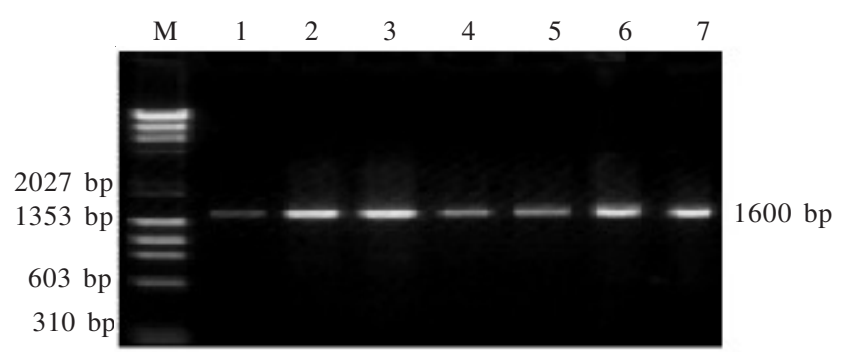

Fig 2 Agarose gel electrophoregram of DNA amplified by PCR using degenerate primers PAL1v 1978 dan PAR1c 715. M, marker (1 kb Ladder), Lanes 1-7: begomovirus infecting pepper. hairpin loop length, contain different structure of GC and AT pairs. Similar repetitive sequence 5'-GGAGACA-3' was found in all of the samples although their relative position to common region varies (Table 2 ).

Phylogenetic Analysis. Relationship between isolates of begomovirus from West Sumatra and other selected begomovirus in GeneBank (Table 3) was evaluated based on "top fragment" sequences. Eleven begomovirus isolates determined in this research could be differentiated into three groups (Fig 4). The first group consisted of 6 isolates (PepTD1-3, PepAG1-4, PepSO3-5, PepAG2-4, PepAG2-1 and PepPSS1-1). The second group consisted of 4 isolates (PepPBST2-3, PepTD2-1, PepPSS2-3 and PepSO2-1), where as the third group consisted of a one isolate, i.e PepPYK1. It is interesting to notice that all isolates collected from Agam (PepAG2-1, PepAG2-4 and PepAG1-4) belong to the same group 1, where as other isolates collected from same location belong to different group, for instance PepTD1-3 and PepTD 2-1, PepPSS1-1 and PepPSS2-3, PepSO3-5 and PepSO2-1. Begomovirus infecting pepper in Indonesia that have been reported earlier (PYLCIV-Bgr, PYLCIV-To, PYLCIV-Lbg, and PYLCIV-ageratum) was not belong in the same group with the begomovirus identified in the present research. However, they are closely related with group 2 of the begomovirus identified from West Sumatra.

In general begomovirus isolates from West Sumatra were tentatively called pepper yellow leaf curl Indonesia virusWest Sumatera-[group1], -[group2] and -[group3] \{PYLCIV-WS-[group1], -[group2] and -[group3]\}, although sequence diversity occurred among eleven isolates from West Sumatra.

\section{DISCUSSION}

Pepper yellow leaf curl disease is considered an important new emerging disease in Indonesia which causes significant damage to plants. Association of begomovirus with the disease was first reported in 1999 in West Java, but by early 2003 the disease ha been found in almost all pepper growing areas in Java (Sulandari 2004). In the same time, Syaiful (2005) reported the incidence of the disease in West Sumatra, and since 2005 epidemics occurred in pepper causing up to $100 \%$ disease incidence (Trisno et al. 2005). The type of symptoms associated with the disease in West Sumatra is different from

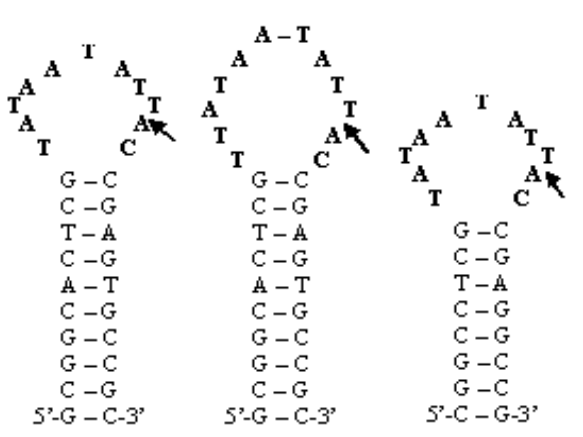

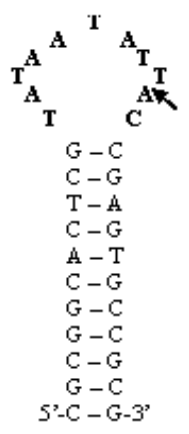

4

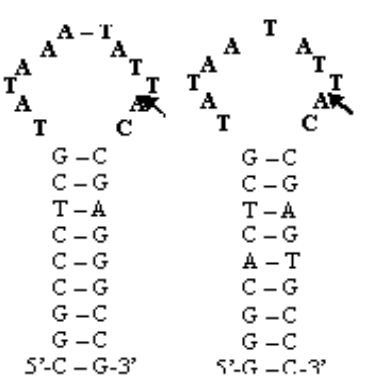

5

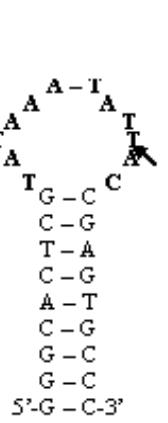

7

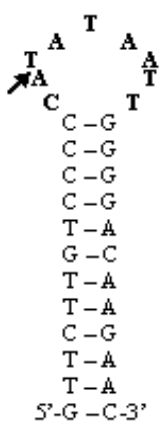

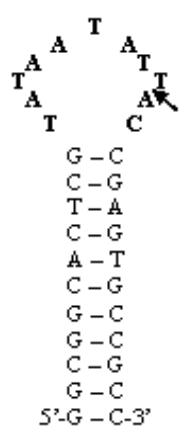

Fig 3 Comparison of the hairpin loop structure of pepper begomovirus. 1, the 31 base hairpin-loop region in PepPYK1, PepAgam2-1, PepAgam2-4, and PepYLCIDV; 2, the 32 base hairpin-loop region in PepSolok2-1; 3, the 27 base hairpin-loop region in PepSolok3-5; 4, the 33 base hairpin-loop region in PepT.datar1-3; 5, the 29 base hairpin-loop region in PepT.datar 2-1; 6, the 29 base hairpin-loop region in PepPSS1-1; 7, the 30 base hairpin-loop region in PepPSS2-3; 8, the 30 base hairpin-loop region in PepPasBt 1; 9, the 33 base hairpin-loop region in PepAgam1-4. The conserved nonanucleotide sequence TAATATT $\downarrow$ AC is in bold, and the nick site is marked by an arrow. 
Table 2 Comparison of iteron upstream of the $\mathrm{C} 1$ gene TATA Box in 11 begomovirus isolates from West Sumatra with PepYLCIV-pepper yellow leaf curl Indonesia virus (AB246170.1), TLCIV-tomato leaf curl Indonesia virus (AB100304) and TLCJAV-tomato leaf curl Java virus (AB162141)

\begin{tabular}{lcc}
\hline Isolate & Iteron (5'-3') & Position $^{\mathrm{x}}$ \\
\hline PepYLCIV & GGAGACA & $-86 \mathrm{~s} / \mathrm{d}-80,-93 \mathrm{~s} / \mathrm{d}-87,-122 \mathrm{~s} / \mathrm{d}-116$ \\
TLCIV $^{y}$ & GGAGACA & $-134 \mathrm{~s} / \mathrm{d}-128,-196 \mathrm{~s} / \mathrm{d}-190$ \\
TLCJAV $^{y}$ & GGGTCTCAA & -102 to $-94,-137$ to -129 \\
PepPYK1 & GGAGACA & $-82 \mathrm{~s} / \mathrm{d}-76,-89 \mathrm{~s} / \mathrm{d}-83,-118 \mathrm{~s} / \mathrm{d}-112$ \\
PepSo2-1 & GGAGACA & $-89 \mathrm{~s} / \mathrm{d}-83,-97 \mathrm{~s} / \mathrm{d}-91,-125 \mathrm{~s} / \mathrm{d}-119$ \\
PepSo3-5 & GGAGACA & $-84 \mathrm{~s} / \mathrm{d}-78,-91 \mathrm{~s} / \mathrm{d}-85,-119 \mathrm{~s} / \mathrm{d}-113$ \\
PepTD1-3 & GGAGACA & $-87 \mathrm{~s} / \mathrm{d}-81,-94 \mathrm{~s} / \mathrm{d}-88,-123 \mathrm{~s} / \mathrm{d}-117$ \\
PepTD2-1 & GGAGACA & $-83 \mathrm{~s} / \mathrm{d}-77,-90 \mathrm{~s} / \mathrm{d}-84,-117 \mathrm{~s} / \mathrm{d}-111$ \\
PepPSS1-1 & GGAGACA & $-88 \mathrm{~s} / \mathrm{d}-82,-95 \mathrm{~s} / \mathrm{d}-89,-122 \mathrm{~s} / \mathrm{d}-116$ \\
PepPSS2-3 & GGAGACA & $-85 \mathrm{~s} / \mathrm{d}-79,-93 \mathrm{~s} / \mathrm{d}-87,-121 \mathrm{~s} / \mathrm{d}-115$ \\
PepPBST2-3 & $-{ }^{z}$ & $-90 \mathrm{~s} / \mathrm{d}-84,-97 \mathrm{~s} / \mathrm{d}-91,-125 \mathrm{~s} / \mathrm{d}-119$ \\
PepAg1-4 & GGAGACA & $-89 \mathrm{~s} / \mathrm{d}-83,-96 \mathrm{~s} / \mathrm{d}-90,-124 \mathrm{~s} / \mathrm{d}-118$ \\
PepAg2-1, PepAg2-4 & GGAGACA &
\end{tabular}

${ }^{x}$ Nucleotide numbering starts from the A adjacent to the nicking site within the conserved nonanucleotide (TAATATT $\downarrow$ AC), ${ }^{\text {y }}$ Database GeneBank, ${ }^{\text {zNona data. }}$

Table 3 List of geminivirus used for phylogenetic analysis (Database Genebank)

\begin{tabular}{|c|c|c|c|c|c|}
\hline \multicolumn{2}{|c|}{$\begin{array}{c}\text { Genebank } \\
\text { Accession Number }\end{array}$} & \multicolumn{2}{|c|}{$\begin{array}{l}\text { Nukleotide's } \\
\text { length (bp) }\end{array}$} & \multirow[t]{2}{*}{ Host plant } & \multirow{2}{*}{$\frac{\text { Acronim }}{\text { PYLCVI-Co }}$} \\
\hline AB246170.1 & $\begin{array}{l}\text { pepper yellow leaf curl } \\
\text { Indonesia virus }\end{array}$ & 2760 & Indonesia, Bogor & & \\
\hline AB 189845 & $\begin{array}{l}\text { pepper yellow leaf curl } \\
\text { Indonesia virus }\end{array}$ & 1563 & Indonesia, Bandung, Lembang & L. esculentum & PYLCVI-T2 \\
\hline DQ083764 & $\begin{array}{l}\text { pepper yellow leaf curl } \\
\text { Indonesia virus-Bogor }\end{array}$ & 2743 & Indonesia, Bogor & Capsicum annuum & TYLCVI-Bgr \\
\hline NC_008267 & $\begin{array}{l}\text { tomato yellow leaf curl } \\
\text { Indonesia virus-Lembang }\end{array}$ & 2762 & Indonesia, Bandung, Lembang & L. esculentum & TYLCVI-Lbg \\
\hline AF189018 & $\begin{array}{l}\text { tomato yellow leaf curl } \\
\text { Indonesia virus-Lembang }\end{array}$ & 2762 & Indonesia, Bandung, Lembang & L. esculentum & TYLCVI-LbA \\
\hline NC 004005 & tomato yellow leaf curl virus & 2781 & Almeria, Spain & L. esculentum & TYLCV \\
\hline NC_005347.1 & pepper yellow vein mali virus & 2786 & Mali & - & PYLVMiV \\
\hline EU585781.1 & pepper leaf curl Yunnan virus & 2747 & China & C. anпиит & PLCYuV \\
\hline AB 162141 & tomato lea curl Java virus & 1562 & Indonesia, Magelang & L. esculentum & TLCJAV \\
\hline AF327436.1 & tomato leaf curl Malaysia virus & 2754 & Malaysia, Klang & L. esculentum & TLCVMal \\
\hline DQ116884.1 & tomato leaf curl Pakistan virus & 2759 & Pakistan & L. esculentum & TLCPaV \\
\hline DQ641697.1 & tomato leaf curl virus Vietnam & 2745 & Vietnam, Hanoi & L. esculentum & TLCVit \\
\hline NC_000869.1 & tomato yellow leaf curl China virus & 2734 & China & L. esculentum & TYLCVCi \\
\hline EU249457.1 & tomato yellow leaf curl Thailan virus & 2743 & Thailan & C. аппиит & TYLCTaiV \\
\hline AJ495813.1 & ageratum yellow vein China virus & 2768 & China, Hainan & Ageratum conizoydes & AYVCiV \\
\hline AB 306314.1 & ageratum yellow vein virus-Ishigaki & 2753 & Japan, Okinawa & L. esculentum & AYLCVishi \\
\hline EF544600 & ageratum yellow vein Taiwan virus & 2753 & China Fujian & Ageratum conizoydes & AYVTaiV \\
\hline AB 189913.1 & ageratum yellow vein virus-Indonesia & 1557 & Indonesia, Bandung, Lembang & Ageratum conizoydes & AYLCIndV \\
\hline X74516.1 & ageratum yellow vein virus & 2741 & China & Ageratum conizoydes & AYVV \\
\hline
\end{tabular}

those found in Java, which commonly caused bright yellow colouring (Sulandari 2004). The differences in symptoms type of the disease between West Sumatra and Java may be caused by the difference of: (i) the type of cultivar used, where Peper cultivars that are generally planted in West Sumatera is the local cultivar "lado keriting darek" (from direct interview with farmers). Meanwhile, the cultivar that is generally planted in Java are an introduction cultivar, such as TM 999, TM 888 and Jatilaba (Sulandari 2004), (ii) the strain of geminivirus; this research showed the different strains of geminivirus excisted between West Sumatera and Java (Fig 4). Idris and Brown (1998) stated that there are different virus strains that cause plant desease with different symptoms. Since high genetic diversity of begomoviruses has been previously reported, it is important to determine the identity of begomovirus infecting pepper crops in West Sumatra.
The identity of begomovirus infecting pepper in West Sumatra was determined based on their hairpin-loop structure and repetitive sequence (iteron) found in the common region. These hairpin loop structure has been found in all geminivirus sequenced so far (Zhou et al. 2003) and iteron is known as the specific-binding site of the geminivirus replicationassociated proteins (Ribeiro et al. 2006). Both the hairpinloop structure and iteron have been found in all geminivirus sequenced to date and this might be used for analysis of their genetic diversity. It was known that differences in the common region may indicate a different begomovirus strain (Hidayat et al. 1999; Chatchawankanphanich and Maxwell 2002; Sukamto et al. 2005; Ribeiro et al. 2006; Santoso et al. 2008). It was found in our present research that three isolates of begomovirus infecting pepper in West Sumatra (PepPYK1-1, PepAg2-1 and PepAg2-4) have a hairpin loop 


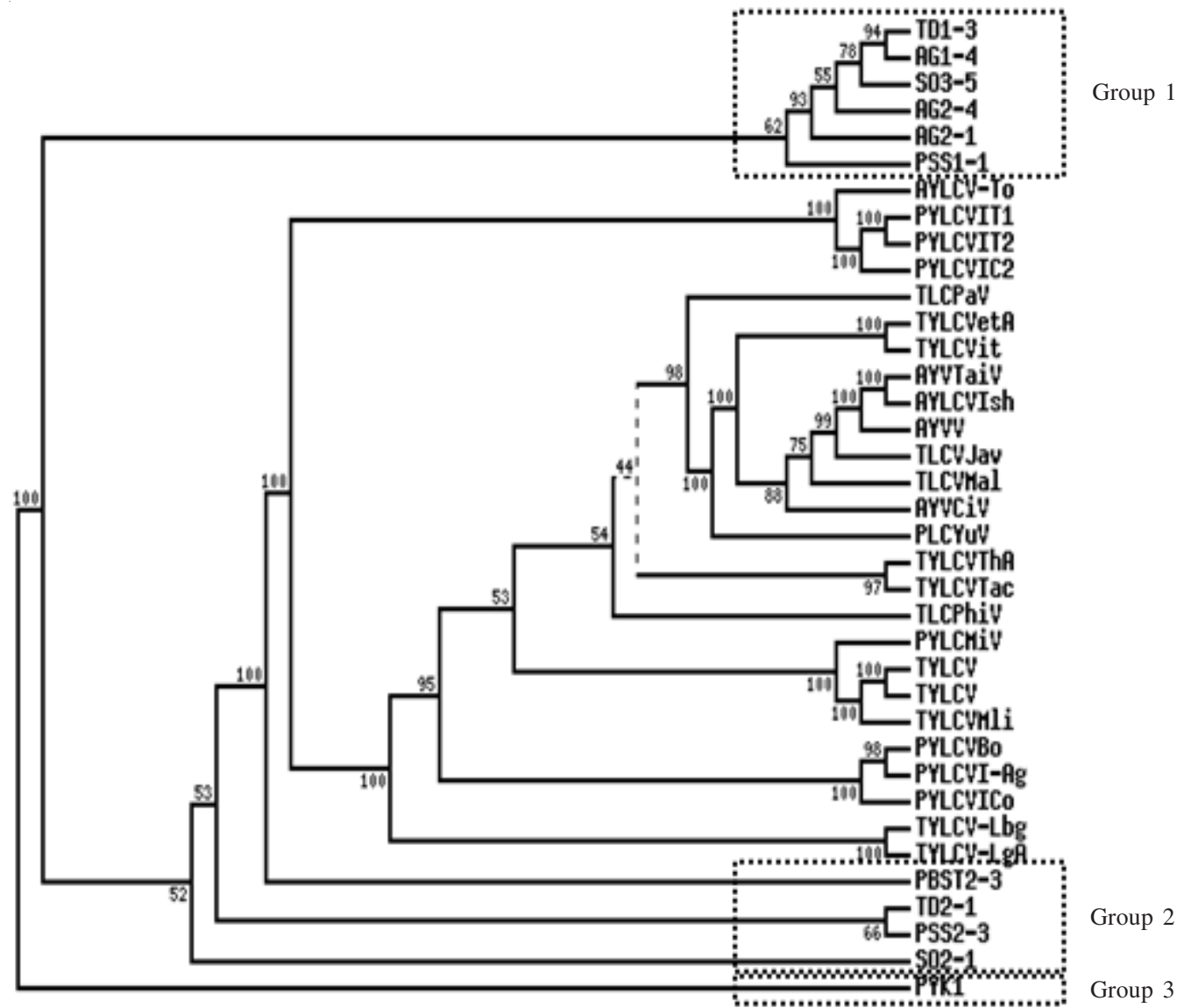

Fig 4 Phylogenetic tree based on the alignments of the common region sequences of pepper-infecting begomovirus from West Sumatra with other selected begomovirus (GeneBank database). Squares ( ) show position of the samples.

structure similar to that of PYLCIV-Bogor (Hidayat et al. 2006), whereas the isolates from the rest of West Sumatra have different structures. Repetitive sequences for most isolates of begomovirus infecting pepper in West Sumatra (GGAGACA) were similar with those of ToLCIV (Sukamto $e t$ al. 2005) and PYLCIV-Bgr (Hidayat et al. 2006), but different from those of ToLCJAV (Sukamto et al. 2005). Differences were also observed with geminiviruses reported from other countries, for instance bean golden mosaic virus-Guatemala (Ikegami et al. 1988), tomato leaf curl Joydebpur virus-Mild (ToLCJV-Mild), and tomato leaf curl New Delhi virus-severe from Jessore (ToLCNDV-Svr[Jes])(Maruthi et al. 2005), each with repetitive sequence of TGCGAGTGTCTCCAA, GGTGT, GGAGT, respectively. Variability in hairpin-loop structure and iteron sequences indicates the possibility of genetic diversity among begomoviruses from West Sumatra. Therefore, further analysis of genome sequences is necessary.

Phylogenetic analysis based on the common-region sequences revealed that the West Sumatra isolates of begomovirus infecting pepper can to differentiated into three groups. Sequence similarity ranged from 63 to $91 \%$ with selected begomoviruses from Asia (Table 3). Padidam et al. (1995) proposed that virus isolates displaying more than $90 \%$ sequence identity sh+ould be considered as isolates or strains rather than different viruses. In this study, strain grouping didnot represent different altitude for sample location, where the group 1 comes from locations sampled at low, medium and high altitudes, i.e. PepPSS1-1, PepSo3-5, PepAg1-4, and PepTD1-3, respectively. We could not make any conclusion yet regarding the identity of begomovirus from West Sumatra based on analysis of he common-region sequences. Availability of the full genome sequence will provide comprehensive and complete analysis enable such a conclusion. However, there is an indication that genetic variability of begomovirus isolates infecting pepper occurred in West Sumatra and that the viruses are related to begomovirus infecting pepper in Java. This fact should be considered in developing strateies to control pepper yellow leaf curl disease, especially in the development of resistant varieties.

\section{ACKNOWLEDGEMENTS}

This research was supported in part by research grant from Department of Agriculture (Kerjasama Kemitraan Penelitian Pertanian dengan Perguruan Tinggi /KKP3T) and Directorate Genderal of Higher Education, Department of National Education, Indonesia (Hibah Bersaing).

\section{REFERENCES}

Chatchawankanpanhich O, Maxwell DP. 2002. Tomato leaf curl Karnata virus from Bangalore, India, appears to be a recombinant begomovirus. J Phytopathology 92:637-45.

Doyle JJ, Doyle JL. 1999. Isolation of plant DNA from fresh tissue. J Focus 12:13-5.

Fauquet CM, Stanley J. 2003. Geminivirus classification and nomenclature: progress and problems. Ann Appl Biol 142:16589.

Gutierrez C. 2000. Strategies for geminivirus DNA replication and celecycle interference. J Physiol Mol Plant Pathol 60:219-30. 
Hidayat SH, Chatchawankanpanich O, Rusli E, Aidawati N. 2006. Begomovirus associated with pepper yellow leaf curl disease in west Java, Indonesia. J Microbiol Indones 11:87-90.

Idris AM. Brown JK. 1998. Sinaola tomato leaf curl geminivirus: biological and molecular evidence for a new subgroup III virus. J Phytopatology 88:648-57.

Ikegami M, Morinaga T, Miura K. 1988. Potential gene products of bean golden mosaic virus have higher sequence homologies to those of tomato golden mosaic virus than those of cassava laten virus. J Virus Genes 1:191-203.

Lapidot M, Friedmen M, Pilowsky M, Ben-Joseph R, Cohen R. 2001. Effect of host plant resistance to tomato yellow leaf curl virus (TYLCV) on virus acquisition and transmission by its whitefly vector. J Phytopathology 91:1209-13.

Maruthi MN, Alam SN, Kader KA, Rekha AR, Colvin J. 2005. Nucleotide sequencing, whitefly transmission, and screening tomato for resistance against two newly described begomoviruses in Banglades. J Phytopathology 95:1472-81

Padidam M, Beachy RN, Fauquet CM. 1995. Clacification and identification of geminivirus using sequence comparation. J Gen Virol 76:249-63

Ribeiro SG, Martin DP, Lacoste C, Simoes IS, Orlandini DRS, InoueNagata AK. 2006. Molecular and biological characterization of tomato chlorotic mottle virus suggests that recomendation underlies the evolution and diversity of Brazilian tomato begomoviruses. J Phytopathology 96:702-11.
Rojas MR, Gilbertson RL, Russel DR, Maxwell DP. 1993. Use of degenerate primers in the polymerase chain reaction to detect whitefly-transmitted geminiviruses. J Plant Dis 77:340-7.

Rusli ES, Hidayat SH, Suseno R, Tjahjono, B. 1999. Geminivirus on pepper: symptom variation and transmission study. Bul HPT 11:126-31.

Santoso TJ, Hidayat SH, Duriat AS, Herman M, Sudarsono. 2008 Indentity and sequence diversity of Begomovirus assciated with yellow leaf curl diseases of tomato in Indonesia. J Microbiol Indones 2:1-7.

Sukamto, Kon T, Hidayat SH, Hase S, Takahashi H, Ikegami. 2005. Begomoviruse associated with leaf curl disease of tomato in Java, Indonesia. J Phytopathology 95:562-6.

Sulandari S. 2004. Karakterisasi biologi, serologi dan analisis sidik jari DNA virus penyebab penyakit daun keriting kuning cabai. [Dissertation]. Bogor: Institut Pertanian Bogor.

Trisno J, Charnita R, Hanafiah A. 2005. Karakteristik gejala dan deteksi virus kuning tanaman cabai di Sumatera Barat. J Manggaro 6:21-9.

Varma A, Malathi VG. 2003. Emerging geminivirus problems: a serious threat to crop production. Ann Appl Biol 142:145-64.

Zhou X, Xie Y, Tao X, Zhang Z, Li Z, Fauquet CM. 2003. Characterization of DNA-b assocated with begomoviruses in China and evidence for co-evolution with their cognate viral DNA-A. J Gen Virol 84:237-247. 